Article

\title{
Effect of polytetrafluoroethylene distribution in the gas diffusion layer on water flooding in proton exchange membrane fuel cells
}

\author{
Wei Song, Hongmei Yu*, Zhigang Shao*, Baolian Yi, Jin Lin, Na Liu \\ Dalian Institute of Chemical Physics, Chinese Academy of Sciences, Dalian 116023, Liaoning, China
}

\section{A R T I C L E I N F O}

Article history:

Received 25 October 2013

Accepted 13 November 2013

Published 20 April 2014

\section{Keywords:}

Fuel cell

Gas diffusion layer

Hydrophobicity

Water flooding

\begin{abstract}
A B S T R A C T
The effect of polytetrafluoroethylene (PTFE) distribution in the gas diffusion layer on water flooding in proton exchange membrane fuel cells was investigated. PTFE was introduced within micropores of carbon papers, to achieve hydrophobicity under different pressures. Carbon papers were subjected to vacuum conditions during immersion in PTFE solution to prepare gas diffusion layers. Residual gas within the carbon papers was eliminated, and PTFE evenly infused within the pores. Cross-sections of the carbon papers indicated that vacuum treatment improved PTFE distribution. The same PTFE content resulted in a decreased water contact angle of the carbon paper because of the greater PTFE content within the micropores. The proportions of hydrophobic and hydrophilic pores within the carbon papers were investigated. The proportion of hydrophobic pores increased during the vacuum treatment. Membrane electrode assemblies (MEAs) were fabricated using the treated hydrophobic carbon papers as gas diffusion layers and were evaluated in a full-sized fuel cell. The uniform PTFE distribution of the carbon paper benefited fuel performance. Electrochemical impedance spectroscopy indicated that the improved MEA possessed favorable resistance to water flooding.
\end{abstract}

(C) 2014, Dalian Institute of Chemical Physics, Chinese Academy of Sciences. Published by Elsevier B.V. All rights reserved.

\section{Introduction}

Proton exchange membrane fuel cells (PEMFC) are devices that convert chemical energy into electricity through electrochemical reaction. PEMFCs are efficient, with fast startup, and produce no emission. They have been applied in vehicles, power stations, uninterruptible power system, and aircraft.

To fully commercialize such fuel cells, their durability must be prolonged, their performance improved, and their cost reduced [1]. The membrane electrode assembly (MEA) performs the core functions of a PEMFC. The MEA consists of two catalytic electrodes and gas diffusion layers (GDLs) on each side of a proton exchange membrane, respectively, for the anode and cathode. Each component of the MEA is optimized to improve the performance, durability, and robustness of the overall PEMFC [2-5]. The GDL sandwiched between the catalyst layer and gas flow channel is an important component concerning the water management of the MEA.

Liquid water in MEAs arises from condensed humidified vapor and as a product of oxygen reduction, some of which is necessary for maintaining the ionic conductivity of the membrane and catalyst layer (CL). Excess water may occlude active sites for electrochemical reaction and affect the gas permeability [6-8]. Most water is transported out of the cathode CL and

\footnotetext{
* Corresponding author. Tel: +86-411-84379051; Fax: +86-411-94379185; E-mail: hmyu@dicp.ac.cn

\# Corresponding author. Tel: +86-411-84379153; Fax: +86-411-94379185; E-mail: zhgshao@dicp.ac.cn

This work was supported by the National High Technology Research and Development Program of China (863 Program, 2011AA050701, 2011AA11A273) and the National Natural Science Foundation of China (21203191).

DOI: 10.1016/S1872-2067(14)60014-0 | http://www.sciencedirect.com/science/journal/18722067 | Chin. J. Catal., Vol. 35, No. 4, April 2014
} 
accumulates at the interface between the CL and GDL before draining from the MEA through the GDL by capillary action [9].

GDLs commonly consist of a substrate and microporous layer (MPL). To achieve water removal and gas diffusion, the substrate is typically waterproofed by introducing polytetrafluoroethylene (PTFE) within micropores. This prevents the GDL surface and pores from being clogged with liquid water and facilitates gas transport to the CL. The treatment process normally results in inhomogeneous PTFE distribution across the GDL substrate, with higher concentrations at the surface. Neutron radiography reportedly indicated that water concentrates in the center of the carbon paper when the fuel cell is operating [10-12], reflecting the fact that GDLs are easily flooded.

In the current study, hydrophobization treatment was used to achieve an even PTFE distribution in carbon paper. By vacuumizing the residual gas within carbon paper pores, PTFE solution can more effectively penetrate the pores. The resulted homogeneous hydrophobic pores exhibit favorable anti-flooding properties.

\section{Experimental}

\subsection{Carbon paper hydrophobization}

PTFE was introduced within the micropores of carbon paper (Toray, Japan, TGP-H-060) for hydrophobization. Carbon papers were immersed in PTFE solution, and excess solvent was removed by drying, leaving PTFE remaining in micropores. Carbon papers were treated by this process at pressures of 0 , -0.08 , and $-0.05 \mathrm{MPa}$, with the resulting samples named $\mathrm{CP}-1$, CP-2, and CP-3, respectively. The PTFE contents of the three carbon paper samples were controlled to ensure that they were constant. The resulting carbon papers were sintered at $240{ }^{\circ} \mathrm{C}$ for $30 \mathrm{~min}$ and then at $340^{\circ} \mathrm{C}$ for $30 \mathrm{~min}$ in a $\mathrm{N}_{2}$ atmosphere.

\subsection{Physical characteristics}

\subsubsection{Hydrophobicity test}

The water contact angle of the carbon paper surface was measured using the KRÜSS DSA100 Drop shape analysis system. A total of $3 \mathrm{ml}$ of distilled water was dropped onto the surface of the carbon paper at room temperature. The contact angle image was recorded $5 \mathrm{~s}$ after the drop was placed. The contact angle was analyzed using the tangent method of Sessile Dropfitting.

\subsubsection{Porosity test}

A $3 \mathrm{~cm} \times 3 \mathrm{~cm}$ section of carbon paper was removed and weighed after hydrophobization. The paper was vacuumized and immersed in water at $20{ }^{\circ} \mathrm{C}$ for $2 \mathrm{~h}$. The surface was wiped dry, and the total weight of the paper and water within hydrophilic pores was recorded. This process was repeated until a constant weight was achieved, from which the hydrophilic pore volume was calculated. Residual water was removed from the pores by drying at $90^{\circ} \mathrm{C}$ under vacuum, and the paper was immersed in dodecane under vacuum at $20^{\circ} \mathrm{C}$ for $2 \mathrm{~h}$. The subse- quent procedure was the same as for that above, and the total pore volume was calculated. The porosity of the carbon paper was measured by the mercury intrusion method with a Poremaster GT60 instrument (Quantachrome).

\subsection{MEA fabrication}

Pt/C (Johnson Matthey, 70 wt\%), Nafion ${ }^{\circledR}$ solution (DuPont $5 \mathrm{wt} \%$ ), and isopropyl alcohol were ultrasonically mixed to prepare the catalyst ink, which was sprayed onto a Nafion ${ }^{\circledR} 211$ membrane to form the catalyst coated membrane (CCM). Carbon powder (XC-72), PTFE solution, and ethanol were mixed to form a homogeneous ink, which was painted onto the carbon paper. The GDL was prepared after sintering at $240{ }^{\circ} \mathrm{C}$ for 30 min and then at $340{ }^{\circ} \mathrm{C}$ for $30 \mathrm{~min}$ in a $\mathrm{N}_{2}$ atmosphere. GDLs were fabricated using CP-1 and CP-2.

A CCM was sandwiched between two GDLs, and two MEAs were hot-pressed, which were relevant to CP-1 and CP-2, respectively (Fig. 1). The active area of the MEAs was $270 \mathrm{~cm}^{2}$.

\subsection{Fuel cell stack test}

A short stack was assembled with a graphite flow field and two stainless steel bipolar plates. Evaluation of green light (G100) with a temperature, gas flow rate and pressure controlled system was used to test the cell performance. $i$ - $V$ curves were measured under an electronic loading (Kikusui, PLZ1004\&PLZ2004). Electrochemical impedance spectra (EIS) were measured with a Kikusui KFM2150 instrument.

\section{Results and discussion}

\subsection{SEM characterization of PTFE distribution}

The carbon papers were characterized after hydrophobization treatment. Cross-sectional SEM images of fresh and treated carbon papers are shown in Fig. 2. The straight line indicates the analyzed cross-section, and the flexural curve indicates the elemental $\mathrm{F}$ distribution measured by an electron probe. Fresh carbon paper contained carbon fibers and organic materials, with $\mathrm{F}$ distributed across the entire section. Introducing PTFE within micropores did not change the morphology of the cross section, but the $\mathrm{F}$ distribution was influenced by

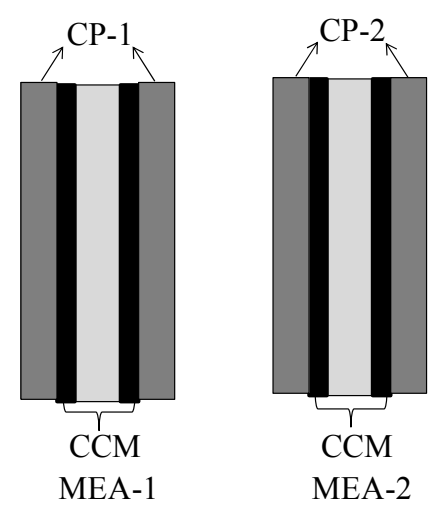

Fig. 1. Sketch map of the MEAs. 

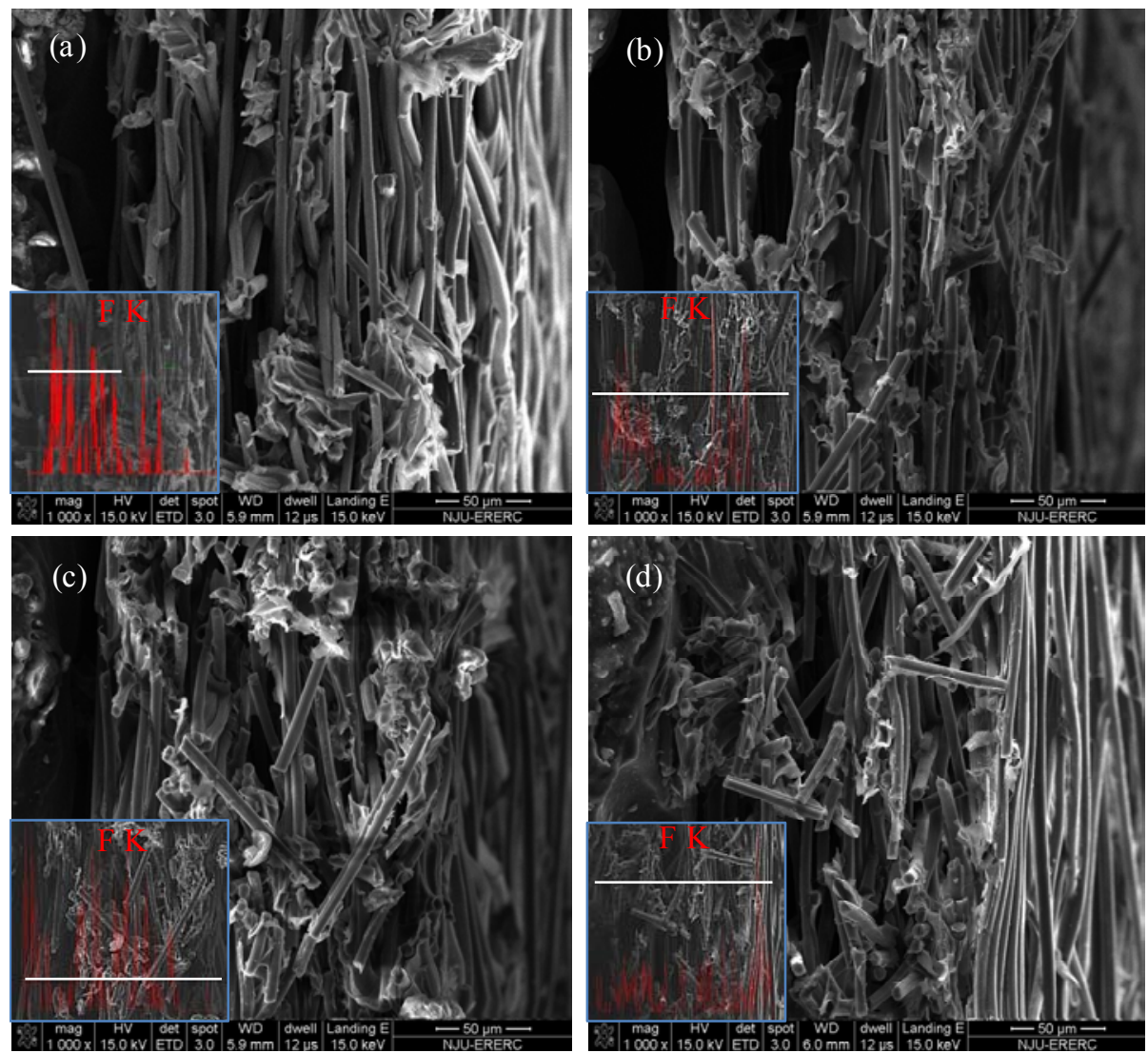

Fig. 2. Cross-sectional SEM images and elemental $\mathrm{F}$ distributions (insets, flexural curve) of fresh carbon paper (a) and carbon papers after introducing PTFE at 0 (b), -0.05 (c), and -0.08 (d) MPa.

Table 1

Weight of carbon papers before and after immersing in water and dodecane, and calculated pore volumes.

\begin{tabular}{|c|c|c|c|c|c|c|c|}
\hline \multirow{2}{*}{$\begin{array}{l}\text { Carbon } \\
\text { paper }\end{array}$} & \multicolumn{3}{|c|}{ Weight (g) } & \multicolumn{3}{|c|}{ Pore size $\left(\mathrm{cm}^{3}\right)$} & \multirow{2}{*}{$\begin{array}{l}\text { Percentage of hydro- } \\
\text { phobic pores (\%) }\end{array}$} \\
\hline & Initial & Immersed in water & Immersed in dodecane & Hydrophilic & Hydrophobic & Total & \\
\hline CP-1 & 0.0926 & 0.1477 & 0.1880 & 0.0551 & 0.0723 & 0.1274 & 56.8 \\
\hline $\mathrm{CP}-2$ & 0.0914 & 0.1431 & 0.1889 & 0.0517 & 0.0785 & 0.1302 & 60.3 \\
\hline
\end{tabular}

vacuum PTFE treatment. CP-1 treated at ambient pressure had a higher PTFE distribution near the paper surface, which may subsequently result in water flooding in the central area and therefore limited gas penetration. CP-2 and CP-3 exhibited more even PTFE distributions.

\subsection{Pore characteristics of carbon papers}

The proportion of hydrophilic and hydrophobic pores was investigated by immersing a carbon paper in water and dodecane. After immersing in water, the hydrophilic pore volume was calculated from the increased weight and water density. After immersing in dodecane, the total pore volume was calculated from the increased weight and dodecane density. The total pore volume consisted of the hydrophilic and hydrophobic pore volume contributions. The proportion of hydrophilic and hydrophobic pores was obtained, as shown in Table 1 . The percentage of hydrophobic pores for CP-1 and CP-2 were $56.8 \%$ and $60.3 \%$, respectively, which indicated that PTFE distribution within the carbon paper was improved by the treat- ment.

The total porosities of carbon papers before and after hydrophobization were also measured by mercury infusion, and pore size distribution curves are shown in Fig. 3. The porosity

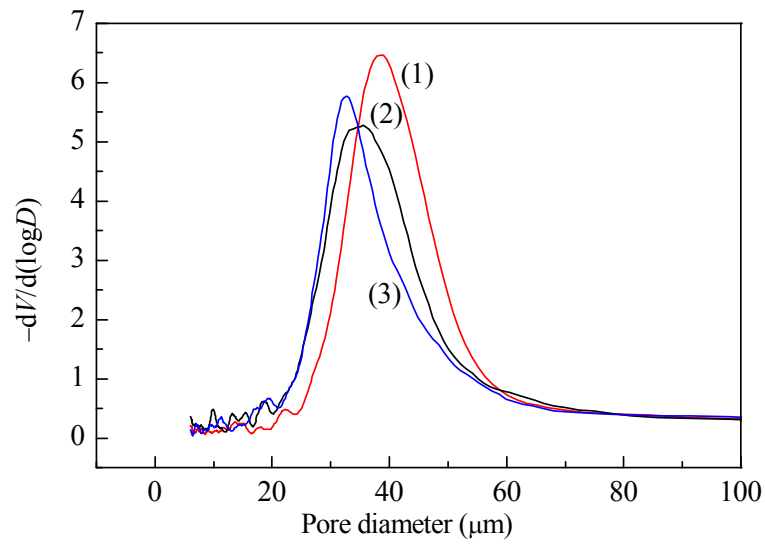

Fig. 3. Pore size distributions of fresh carbon paper (1) and carbon papers after introducing PTFE at 0 (2) and -0.08 (3) MPa. 
of carbon paper largely depended on the density of the carbon fiber and binder. Thus, porosity did not significantly change upon hydrophobization. The predominant pore size of fresh carbon paper was concentrated near $40 \mu \mathrm{m}$, while those of CP-1 and CP-2 were 35 and $30 \mu \mathrm{m}$, respectively. This suggested that the PTFE within the carbon paper may have influenced the pore size distribution.

\subsection{Surface hydrophobicity of carbon papers}

The total amount of immersed PTFE was constant for CP-1 and CP-2. The PTFE distribution within carbon paper was improved by vacuumizing the hydrophobization treatment, so the PTFE content on the CP-2 surface was lower than that on CP-1. Water contact angles on carbon paper were measured to determine surface hydrophobicity, which may have changed with surface PTFE content. A base line was drawn across the two droplet-paper intersections, as shown in Fig. 4. The left and right contact angles between the baseline and tangents across the two intersections were obtained. The contact angles of $\mathrm{CP}-1, \mathrm{CP}-2$, and fresh carbon paper were $150^{\circ}, 145^{\circ}$, and $134.7^{\circ}$, respectively. This indicated that the surface hydrophobicity of carbon paper was improved by introducing PTFE and was related to the PTFE content of the surface.

\subsection{Effect of carbon paper PTFE distribution on cell performance}

Two GDLs were formed by adding a microporous layer to the carbon paper. By sandwiching a self-fabricated CCM with the prepared GDLs, two MEAs were prepared. MEA-1 and MEA-2 incorporated CP-1 and CP-2, respectively. A short stack was assembled and activated to measure cell performance, as shown in Fig. 5. MEA-2 containing carbon paper treated by immersing under vacuum conditions exhibited better performance at high current density, especially at current densities > $0.8 \mathrm{~A} / \mathrm{cm}^{2}$. For MEA-1, water tended to accumulate in the center of the carbon paper because of the lower PTFE content at this point, and this may have influenced gas diffusion. Hydrophobization treatment under vacuum resulted in PTFE more efficiently penetrating into the center of the carbon paper, which ensured effective gas diffusion. Such characteristics were manifested in the better cell performance for MEA-2.

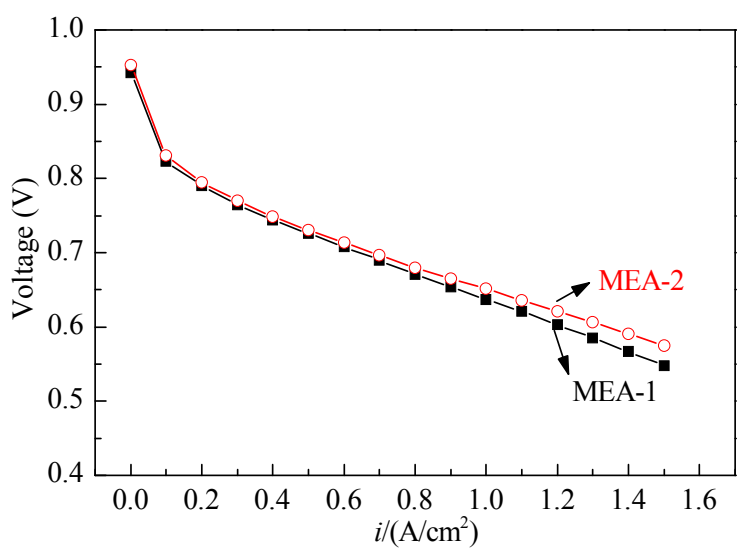

Fig. 5. Performance of cells containing MEAs based on CP-1 and CP-2. Temperature of cell $62{ }^{\circ} \mathrm{C}$, pressure of cell $0.09 \mathrm{MPa}$, stoicheiometry of $\mathrm{H}_{2} /$ air 1.5/2.5.

\subsection{Effect of carbon paper PTFE distribution on EIS}

Nyquist plots of the two MEAs at $1 \mathrm{~A} / \mathrm{cm}^{2}$ are shown in Fig. 6 as dispersed point. Hydrogen oxidation was sufficiently fast that the impedance of the anode could be neglected. Thus, the EIS polarization resistance reflected that of the cathode. The high frequency intercept with the real axis typically represents the ohmic resistance $\left(R_{\mathrm{ohm}}\right)$ of a single cell, indicating the re-

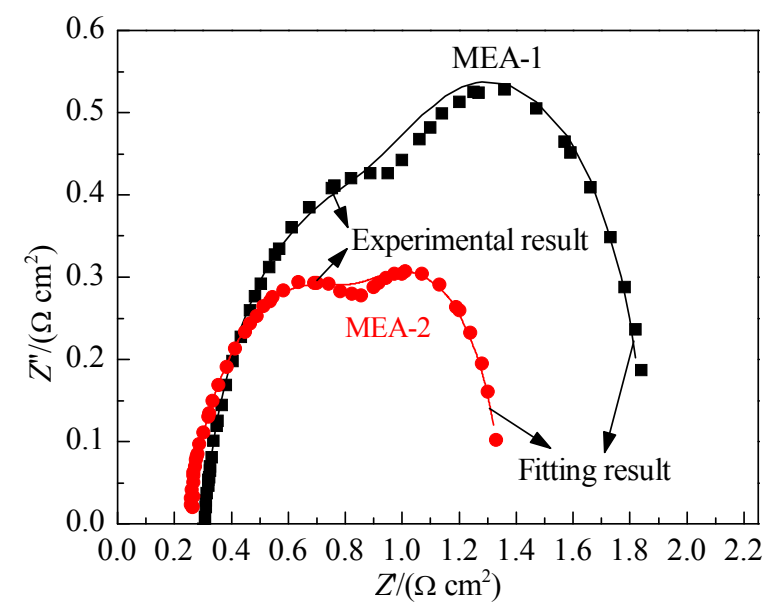

Fig. 6. EIS of MEAs based on CP-1 (square) and CP-2 (circular). Temperature of cell $62{ }^{\circ} \mathrm{C}$, pressure of cell $0.07 \mathrm{MPa}$, stoicheiometry of $\mathrm{H}_{2} /$ air $1.5 / 2.5$. (a)
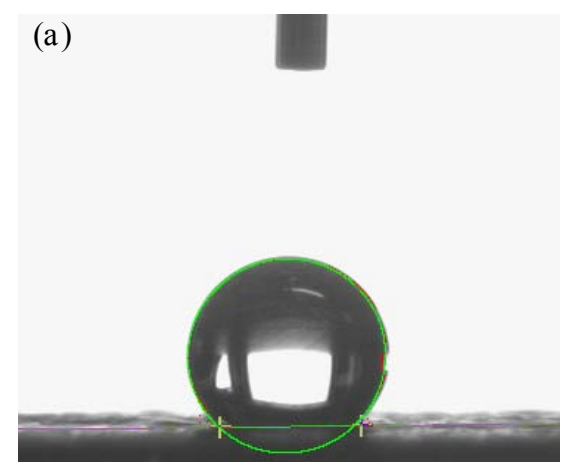

(b)

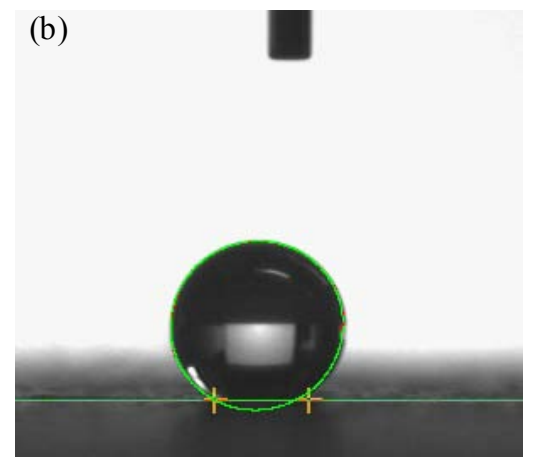

(c)

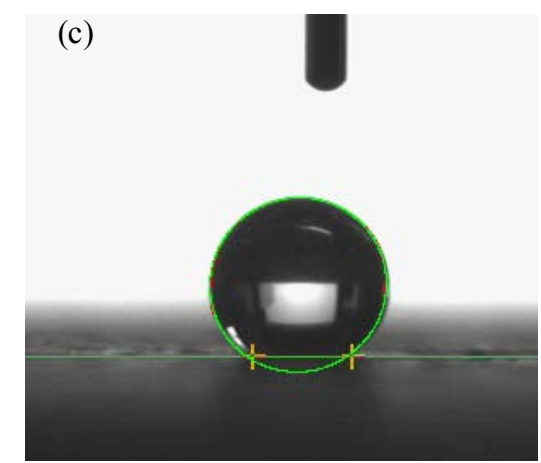

Fig. 4. Water contact angles of fresh carbon paper (a) and carbon papers after introducing PTFE at 0 (b) and -0.08 (c) MPa. 


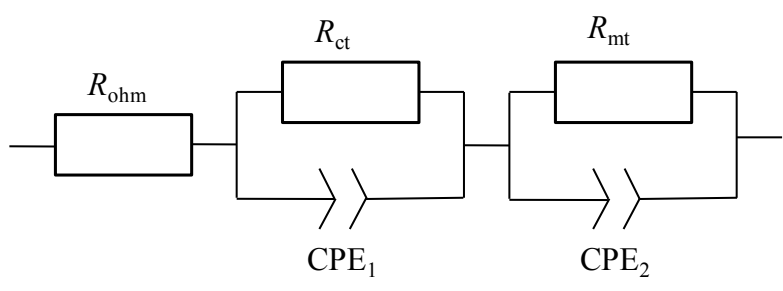

Fig. 7. Equivalent circuit for curve fitting.

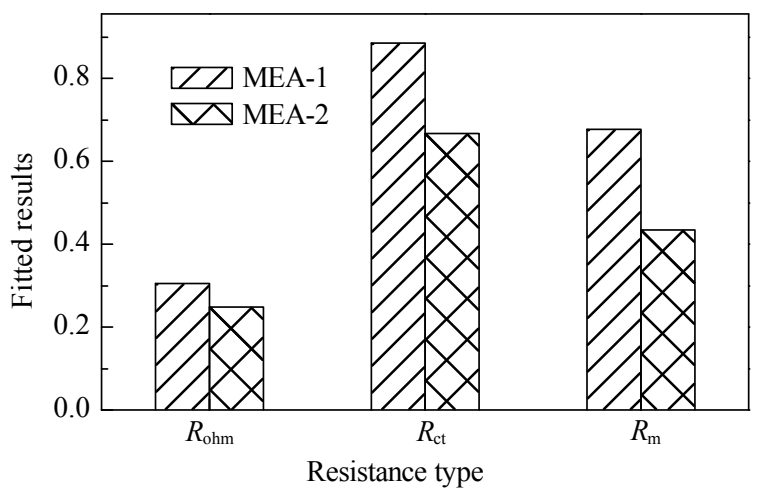

Fig. 8. Comparison of EIS fitting results.

sistance of materials and the contact resistance between them. The first EIS arc relates to the charge transfer resistance $\left(R_{\mathrm{ct}}\right)$ during oxygen reduction and double layer capacitance within the catalyst layer. The second EIS arc relates to the gas diffusion resistance $\left(R_{\mathrm{m}}\right)$. Using the equivalent circuit shown in Fig. 7, EIS spectra were fitted using commercial ZSimpWin software. Comparison of the fitting results (Fig. 8) showed that $R_{\text {ohm }}$ decreased slightly, while $R_{\mathrm{ct}}$ and $R_{\mathrm{m}}$ decreased more significantly. All components within the two MEAs were constant except for the hydrophobization treatment, so the decreased resistances were attributed to the more even PTFE distribution. Such PTFE distribution discouraged water accumulation in the center of the carbon paper and enhanced gas diffusion. Oxygen reduction was subsequently accelerated and $R_{\text {ct }}$ decreased. The greater resistance to water flooding may have further favored $R_{\mathrm{ohm}}$.

\section{Conclusions}

PTFE could not thoroughly penetrate into the center of carbon paper upon conventional hydrophobization treatment, and water flooding occurred at high current density. Vacuumizing the carbon paper during immersion in PTFE solution improved PTFE distribution in the GDL. The surface hydrophobicity of the carbon paper decreased because of the lower PTFE content resulting from the vacuum treatment. However, the cell performance increased significantly. We investigated the proportion of hydrophobic and hydrophilic pores by immersing the carbon paper in different solvents and measuring its increased weight. Hydrophobization treatment under vacuum increased the proportion of hydrophobic pores, resulting in a more even PTFE distribution. Cell performance and fitted EIS spectra indicated that polarization resistance was improved for the MEA containing vacuum treated carbon paper. The mass transport controlling region may have shifted to higher current density.

\section{References}

[1] Wu J F, Yuan X Z, Martin J J, Wang H J, Zhang J J, Shen J, Wu S H, Merida W.J Power Sources, 2008, 184: 104

[2] Prasanna M, Cho EA, Lim T H, Oh I H. Electrochim Acta, 2008, 53: 5434

[3] Lin J F, Wertz J, Ahmad R, Thommes M, Kannan A M. Electrochim Acta, 2010, 55: 2746

[4] Mitsuharu C, Hirofumi D. Electrochem Commun, 2006, 8: 1304

[5] Sui S, Zhuo X L, Su K H, Yao X Y, Zhang J L, Du S F, Kendall K. J Energy Chem, 2013, 22: 477

[6] Matamoros L, Brüggemann D. J Power Sources, 2006, 161: 203

[7] Yan Q G, Toghiani H, Wu J X.J Power Sources, 2005, 158: 316

[8] Nakamura S, Nishikawa H, Aoki T, Ogami Y.J Power Sources, 2009, 186: 278

[9] Nishiyama E, Murahashi T. J Power Sources, 2011,196: 1847

[10] Manahan M P, Hatzell M C, Kumbur E C, Mench M M. J Power Sources, 2011, 196: 5573

[11] Turhan A, Kim S, Hatzell M, Mench M M. Electrochim Acta, 2010, 55: 2734

[12] Kang K, Oh K, Park S, Jo A, Ju H. J Power Sources, 2012, 212: 93

\section{Graphical Abstract}

Chin. J. Catal., 2014, 35: 468-473 doi: 10.1016/S1872-2067(14)60014-0

Effect of polytetrafluoroethylene distribution in the gas diffusion layer on water flooding in proton exchange membrane fuel cells

Wei Song, Hongmei Yu*, Zhigang Shao*, Baolian Yi, Jin Lin, Na Liu Dalian Institute of Chemical Physics, Chinese Academy of Sciences

Hydrophobicity treatment under vacuum resulted in a more even polytetrafluoroethylene (PTFE) distribution in the gas diffusion layer, which inhibits water flooding in proton exchange membrane fuel cells.

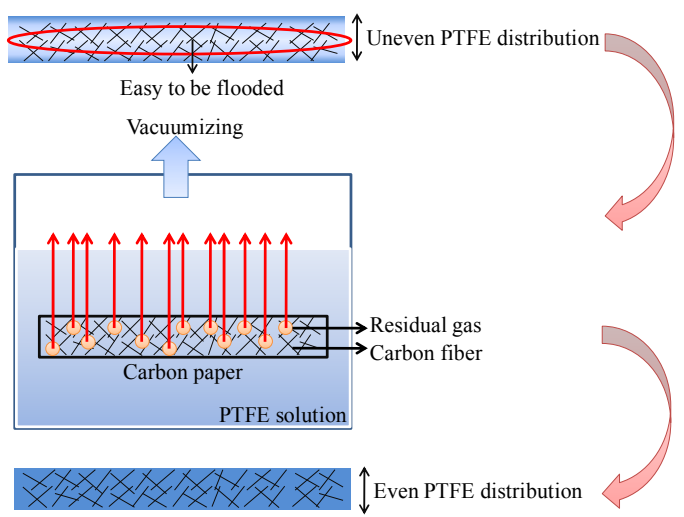




\title{
气体扩散层中聚四氟乙烯的分布对质子交换膜燃料电池水淹的影响
}

\author{
宋 微, 俞红梅, 邵志刚”, 衣宝廉, 林 瑾, 刘 娜 \\ 中国科学院大连化学物理研究所, 辽宁大连 116023
}

摘要: 通过在不同真空度下进行碳纸的聚四氟乙烯(PTFE)浸渍处理, 考察了PTFE在碳纸中的分布对燃料电池水淹情况的影响. 碳纸PTFE浸渍过程中, 抽真空作用可以将碳纸微孔中存留的空气移除, 使PTFE更均匀地扩散到内部微孔中. 碳纸的断面电镜照 片显示真空浸渍可以改善PTFE的分布. 在总浸渍量相同时, 由于真空浸渍使更多的PTFE进入到碳纸内部微孔, 故其表面的PTFE 比例减少. 实验进一步考察了碳纸中亲水孔和憎水孔的分布, 结果表明真空浸渍处理的碳纸具有更高比例的憎水孔. 将不同处理 方法的碳纸制备成膜电极, 通过全尺寸电池考察其性能, 结果表明PTFE的均匀分布可以改善电池性能, 并且电化学阻抗分析表明 其有利于改善水淹问题.

关键词: 燃料电池; 气体扩散层; 憎水性; 水淹

收稿日期: 2013-10-25. 接受日期: 2013-11-23. 出版日期: 2014-04-20.

*通讯联系人. 电话: (0411)84379051; 传真: (0411)84379185; 电子信箱: hmyu@dicp.ac.cn

\#通讯联系人. 电话: (0411)84379153; 传真: (0411)84379185; 电子信箱: zhgshao@dicp.ac.cn

基金来源：国家高技术研究发展计划(863计划, 2011AA050701, 2011AA11A273); 国家自然科学基金(21203191).

本文的英文电子版由Elsevier出版社在ScienceDirect上出版(http://www.sciencedirect.com/science/journal/18722067). 